\title{
Comparison of the chitinolytic properties of Clostridium sp. strain 9.1 and a chitin-degrading bacterium from the intestinal tract of the plaice, Pleuronectes platessa (L.)
}

\author{
Roel Pel, ${ }^{*} \dagger$ Arjan J. van den WijngaArd, Eric Epping and Jan C. GotTschal \\ Department of Microbiology, University of Groningen, 9751 NN Haren, The Netherlands
}

(Received 4 October 1989; accepted 22 December 1989)

\begin{abstract}
The chitinolytic properties of a facultatively anaerobic bacterium isolated from the hindgut of plaice were compared with those of Clostridium sp. strain 9.1, a bacterium isolated from anoxic estuarine sediment. The chitinolytic enzyme systems of the gut isolate and strain 9.1 both released $N, N^{\prime}$-diacetylchitobiose $\left(\mathrm{NAG}_{2}\right)$ as the major hydrolysis end-product. During the hydrolysis of chitin, there was transient accumulation of a nonsedimentary chitin fraction which was not detectable by high-performance liquid chromatography. Growth on $\mathrm{NAG}_{2}$ repressed chitinase synthesis in the gut isolate but not in the Clostridium species. Thiol reagents were strongly inhibitory to the chitinase of the strict anaerobe but did not affect the hydrolytic enzymes of the gut isolate. When the two bacteria were cocultured with chitin as the sole carbon and energy source, Clostridium sp. strain 9.1 was always outcompeted. Experiments with batch and phauxostat cultures showed that the competitiveness of strain 9.1 could be improved dramatically by the inclusion in the cocultures of a non-chitinolytic bacterium capable of fermenting chitin oligomers. The cooperation between the oligomer-fermenting species and the Clostridium sp. is discussed in relation to the regulation of chitinolytic activity in the latter organism.
\end{abstract}

\section{Introduction}

Recently we reported the isolation of eight strains of obligately anaerobic chitin-degrading bacteria, all belonging to the genus Clostridium (Pel \& Gottschal, 1986). The bacteria were isolated from a chitinolytic community, which had been enriched from the upper layer of a tidal mud flat in the Eems-Dollard estuary, The Netherlands. One of these isolates, Clostridium sp. strain 9.1, has been examined in detail. Pure culture studies demonstrated poor growth of this highly specialized chitinolytic anaerobe (Pel \& Gottschal, 1986). The influence of strong reductants and thiol reagents on the apparently redox-sensitive chitinolytic enzyme system has been reported (Pel \& Gottschal, 1986, 1987). In the presence of non-hydrolytic sugar-fermenting or sulphate-

$\dagger$ Present address: Institute for Soil Fertility, 9751 PK Haren, The Netherlands.

Abbreviations: DNS, dinitrosalicylic acid; DP, degree of polymerization; HPLC, high-performance liquid chromatography; IoAc, iodoacetate; NAG, $N$-acetylglucosamine; $\mathrm{NAG}_{2}, N, N^{\prime}$-diacetylchitobiose; NEM, $N$-ethylmaleimide; pCMB, 4-chloromercuribenzoic acid; pCMPS, 4-chloromercuriphenyl sulphonic acid; TOC, total organic carbon. reducing bacteria a strong enhancement of the rate of chitin degradation was observed, due to the release of growth factors by the secondary populations (Pel et al., 1989; Pel \& Gottschal, 1989). One of these factors was a thermostable high-molecular-mass compound, probably identical to the redox-active enzyme thioredoxin ( $\mathrm{Pel} \&$ Gottschal, 1989). Some additional, not yet fully identified, low-molecular-mass factors have also been shown to stimulate growth (Pel et al., 1989).

Previously we have argued that the flow of organic carbon in the Eems-Dollard estuary is not dominated by cellulose but that chitinous particulate matter from crustacean exuviae probably represents a major source of organic carbon in the sediments. However, although no detailed information is available on the quantity of chitin entering the sediments in this estuary (or other estuarine ecosystems), the flux of this polysaccharide will be low in comparison with fluxes existing in the digestive tracts of marine fish that daily consume crustaceans. For example, in the plaice Pleuronectes platessa $(\mathrm{L}$.), known to feed primarily on small crustacea such as Corophium volutator (Stam, 1984), a residence time in the intestinal tract of 10-24 h has been reported (Fänge \& Grove, 1979). Therefore, the digestive tract of this fish, especially the anoxic intestine with a $\mathrm{pH}$ of 7.4-8.5 (Barrington, 1957), 
is likely to harbour (facultatively) anaerobic species capable of rapid degradation of chitinous material.

Studies on the occurrence of chitinolytic bacteria in the digestive tracts of other marine fish have been restricted to the total chitinase activity in situ and the assessment of the number of bacteria capable of aerobic growth on chitin-agar plates. The number of chitin decomposers reported by Seki \& Taga (1963), Goodrich \& Morita (1977) and Danulat (1986) for the marine fish Canthigaster rivulatus, Enophrys bison and Gadus morhua, respectively, were in the range of $10^{7}-10^{9}$ per $\mathrm{ml}$ of intestinal contents. The chitin-degrading potential of the predominant chitinolytic bacteria from these marine fish has never been studied in pure culture, and its importance for chitin degradation in the intestinal tract has been questioned by Danulat (1986).

In this paper we report the isolation of the dominant chitinolytic bacterium from the hind gut of $P$. platessa. Growth characteristics and some properties of the chitinolytic enzyme system of this organism are presented and compared with those of Clostridium sp. strain 9. 1. The apparent absence of these chitinolytic intestinal bacteria from the upper layer of the sediment in the Eems-Dollard estuary is discussed in relation to data obtained from competition experiments conducted in batch and phauxostat cultures.

\section{Methods}

Fish and diet. Pleuronectes platessa (L.), age group 1 to 2 (length approx. $17 \mathrm{~cm}$ ), were obtained from the Department of Marine Biology, University of Groningen. The fish had been caught as breed (fingerlings) in the Marsdiep (outlet of the Waddensea, in the north of the Netherlands) and were kept in a tank containing sea water at $15^{\circ} \mathrm{C}$. They were fed live shrimps (Crangon crangon) every $2 \mathrm{~d}$.

Intestinal sampling and enumeration of chitinolytic bacteria. The intestinal tract of the fish was dissected aseptically under a flow of $\mathrm{N}_{2}$ and cut into four pieces of approximately equal length. Each piece was transferred to a screw-cap Hungate tube $(13 \mathrm{ml})$ containing $\mathrm{Na}_{2} \mathrm{~S}-$ reduced medium and six glass beads ( $3 \mathrm{~mm}$ diameter). The tubes were then closed and the head-spaces were flushed with $\mathrm{N}_{2} / \mathrm{CO}_{2}(80: 20$, $\mathrm{v} / \mathrm{v}$ ). The tubes were thoroughly shaken until most of the gut contents had been released from the lumen. The suspended intestinal contents were then serially diluted into Hungate tubes containing liquid medium amended with ball-milled chitin $(0 \cdot 1 \%, w / v)$. The wet weight of lumen contents of each intestinal piece was estimated by weighing the tubes after the addition, and again after the empty gut pieces had been removed from the tubes (when the dilutions had been made). After incubation of the dilution series for 2 weeks at $25^{\circ} \mathrm{C}$, the tubes in which chitin degradation had occurred were scored, thus providing a rough estimate of the number of chitinolytic anaerobes in each intestinal section.

Isolation of chitinolytic bacteria. The highest positive dilution from the series inoculated with the hindgut section was used for the isolation of the predominant chitinolytic bacterium. A $1 \mathrm{ml}$ sample was serially diluted into pre-reduced chitin-agar medium as described previously (Pel \& Gottschal, 1986). The isolate obtained was designated as strain AW.D2.
Organisms and cultivation. The chitinolytic Clostridium sp. strain 9.1 is only capable of utilizing chitin and chitin oligomers (not $\mathrm{N}$ acetylglucosamine, NAG), with acetate, ethanol, $\mathrm{H}_{2}$ and $\mathrm{CO}_{2}$ as the major fermentation products. Further growth characteristics of this bacterium have been described in earlier papers (Pel \& Gottschal, 1986, 1987).

Non-chitinolytic NAG(-oligomer)-fermenting bacteria used in mixed-culture fermentations of chitin with either one of the chitindegrading species were: a wild-type strain of Escherichia coli (Pel \& Gottschal, 1989), 'Klebsiella aerogenes' (K. pneumoniae) ATCC 15380, and the facultative anaerobes strain HA 8.1 and strain GH 8.2. These latter two bacteria were isolated from the chitinolytic community containing Clostridium sp. strain 9.1. Data on the growth of these bacteria on NAG(-oligomers) and the construction of cocultures are presented elsewhere (Pel et al., 1989).

Pure- and mixed-culture fermentations of chitin (initial concentration $1 \mathrm{mg} \mathrm{ml}^{-1}$ ) in batch culture were conducted using a mineral brackish medium as described previously (Pel et al., 1989). Cultures were maintained in $17 \mathrm{ml}$ screw-cap Hungate tubes containing $13 \mathrm{ml}$ liquid medium $\left(\mathrm{N}_{2} / \mathrm{CO}_{2}, 80: 20, \mathrm{v} / \mathrm{v}\right.$, in the head-space) and incubated at $25^{\circ} \mathrm{C}$ on a rotary shaker run at 80 r.p.m.

For studies conducted in a phauxostat (Martin \& Hempfling, 1976) the bicarbonate buffer in the medium was replaced by a $5 \mathrm{~mm}$ phosphate buffer. The $\mathrm{pH}$ of the medium was adjusted to 7.2 with $\mathrm{NaOH}$. Medium and chitin were delivered separately by two independent peristaltic metering pumps (Vario Perspex 12000, LKB Produkter). The pumps were turned on when the culture $\mathrm{pH}$ fell below 6.6. The buffer capacity of the medium and the chosen $\mathrm{pH}$ set-point value of 6.6 allowed a fermentation of approximately $0.4 \mathrm{mg}$ chitin per $\mathrm{ml}$ culture fluid. The culture vessel was gassed with $\mathrm{O}_{2}$-free $\mathrm{N}_{2}$ delivered by a third pump, also triggered by the culture $\mathrm{pH}$. Especially at low dilution rates, a controlled and small flow of $\mathrm{N}_{2}$ over the culture vessel appeared necessary to ensure that gassing with $\mathrm{N}_{2}$ affected the concentration of dissolved volatile acid-equivalents $\left(\mathrm{CO}_{2}\right.$ and acetate $)$ to the same extent at all flow rates of the medium. The ratio of the supply rates of $\mathrm{N}_{2}$ gas and fresh medium approximated the headspace/liquid-volume ratio of the culture vessel.

Chitinase assay. A turbidimetric assay with resting cells was adopted that minimized the chance of enzyme inactivation due to the absence of substrate as indicated by preliminary experiments in the case of strain AW.D2. To this end, cultures were harvested when approximately $25 \%$ of the initial amount of chitin had been hydrolysed. The pellets were washed three times with a cold deoxygenated phosphate buffer $\left(0{ }^{\circ} \mathrm{C}\right)$ containing $20 \mathrm{~mm}$-sodium phosphate $(\mathrm{pH} 7 \cdot 2) 1 \mathrm{~mm}-\mathrm{CaCl}_{2}$ and $210 \mathrm{mM}-\mathrm{NaCl}$. Ca ${ }^{2+}$ was added as it could possibly increase the stability of chitinase as shown for some polysaccharases (Johnson et al., 1982; Mackenzie et al., 1985; Skujins et al., 1970). The pellets were then resuspended in $13 \mathrm{ml}$ screw-cap Hungate tubes containing $8 \mathrm{ml}$ of the same buffer to a final concentration of approximately $0.6 \mathrm{mg}$ chitin $\mathrm{ml}^{-1}$. Because of the presence of susceptible thiol groups in the chitinolytic system of strain 9.1 (Pel \& Gottschal, 1987), the headspaces of the tubes were flushed with $\mathrm{O}_{2}$-free $\mathrm{N}_{2}$ and subsequently $1 \mathrm{~mm}$-sulphide was added to ensure strictly anaerobic conditions. Rifampicin was added to a final concentration of $50 \mu \mathrm{g} \mathrm{ml}^{-1}$ in order to prevent growth. The tubes were incubated horizontally on a rotary shaker at 250 r.p.m. at a temperature of $37^{\circ} \mathrm{C}$. The incubation periods in the assays were approximately 20 and $40 \mathrm{~h}$ for strain AW.D2 and strain 9.1 , respectively.

Chitinolytic activity resulting in extensive hydrolysis of chitin was monitored by recording the $\mathrm{OD}_{660}$ of the chitin suspension in the tubes. Truly soluble products of chitinolysis were determined in the supernatant of the assay fuid after sedimentation of residual chitin by centrifugation at $8500 \mathrm{~g}$ for $5 \mathrm{~min}$. Non-sedimentable chitin fragments and dextrins in the supernatant were determined after acid hydrolysis 
and a subsequent colorimetric determination of the glucosamine formed. The degree of solubilization obtained in the chitinase assay was calculated from the amount of organic carbon in the supernatants and the total amount of chitin-carbon initially present.

Chemical analyses. Fermentation products (Pel \& Gottschal, 1986), residual chitin (Pel \& Gottschal, 1989), NAG (Pel \& Gottschal, 1986), NAG-oligomers (Pel et al., 1989) and total organic carbon (TOC) (Pel \& Gottschal, 1986) were determined as described previously. Total reducing sugar was analysed by the dinitrosalicylic acid (DNS) method as described by Miller (1959). Standard curves for NAG and chitobiose in the DNS assay indicated that both sugars exhibited a nearly equal colorimetric response expressed per mole of (di)saccharide. Nonsedimentable chitin fragments and dextrins were determined as glucosamine. $\mathrm{HCl}$ after acid hydrolysis $(6 \mathrm{M}-\mathrm{HCl})$ as described by $\mathrm{Chen}$ \& Johnson (1983)

Chemicals. Chitin (practical grade), glucosamine, NAG, $N, N^{\prime}$ diacetylchitobiose $\left(\mathrm{NAG}_{2}\right)$, 4-chloromercuribenzoic acid (pCMB), 4chloromercuriphenlysulphonic acid (pCMPS), iodoacetate (IoAc) and $\mathrm{N}$-ethylmaleimide (NEM) were purchased from Sigma. Finely dispersed chitin and NAG-oligomers with degrees of polymerization (DP) up to six sugar residues were prepared as described previously (Pel \& Gottschal, 1986). All other chemicals used were reagent grade.

\section{Results}

\section{Isolation and growth characteristics of strain $A W . D 2$}

All dissected parts of the intestinal tract of the plaice contained approximately $10^{9}$ chitinolytic bacteria per $\mathrm{ml}$ gut content, except the one comprising the small intestines, which contained approximately $10^{6}$ bacteria $\mathrm{ml}^{-1}$. Strain AW.D2 was isolated as the predominant chitinolytic bacterium from the intestinal part containing the hindgut. It was a facultatively anaerobic, Gramnegative, rod-shaped $(0.5-0.8 \times 1.5-2.5 \mu \mathrm{m})$, nonsporing bacterium, motile by one or two polar flagella. Acetate, ethanol and formate were the major fermentation products during growth on chitin and NAG (Table 1). The rate of chitin fermentation was influenced by the intensity of agitation of the cultures. Both continuous stirring and static incubations slowed down the rate of chitinolysis. The highest rates were recorded when chitin particles were merely kept in suspension by incubating the cultures in Hungate tubes positioned horizontally on a rotary shaker run at 80 r.p.m.

Fig. 1. shows the time courses of chitin degradation by strain AW.D2 and Clostridium sp. strain 9.1 in monoand coculture. Sometimes a partial loss of chitinolytic activity was observed when strain AW.D2 was maintained on NAG-agar aerobically. Degradation of chitin by strain AW.D2 occurred aerobically at a similar rate as that recorded anaerobically. The temperature range for anaerobic growth was from 5 to $37^{\circ} \mathrm{C}$ with an optimum at $30^{\circ} \mathrm{C}$. The $\mathrm{pH}$ optimum for growth of strain AW.D2 ranged from $7 \cdot 0$ to 8.0 ; no growth occurred at pH 5.0 and $9 \cdot 0$. Supplementation of the growth medium
Table 1. Products of chitin and NAG fermentation by strain $A W . D 2$ and of chitin fermentation by Clostridium sp. strain 9.1

Bacteria were grown in a medium buffered with $30 \mathrm{~mm}$-phosphate (pH 7.2). In the headspace, $100 \% \mathrm{~N}_{2}$ replaced the $\mathrm{N}_{2} / \mathrm{CO}_{2}$ mixture usually applied.

\begin{tabular}{|c|c|c|c|}
\hline \multirow[b]{3}{*}{ Product } & \multicolumn{3}{|c|}{ Amount of product* } \\
\hline & \multicolumn{2}{|c|}{ Strain AW.D2 } & \multirow{2}{*}{$\frac{\text { Strain } 9.1 \dagger}{\text { Chitin }}$} \\
\hline & Chitin & NAG & \\
\hline Acetate & 157 & 137 & 117 \\
\hline Formate & 121 & 171 & 10 \\
\hline Lactate & 12 & 17 & - \\
\hline Succinate & 5 & 3 & - \\
\hline Ethanol & 69 & 90 & 81 \\
\hline $\mathrm{CO}_{2}$ & 21 & 31 & 150 \\
\hline $\mathrm{H}_{2}$ & - & - & 106 \\
\hline Carbon recovery & $98 \%$ & $95 \%$ & $84 \%$ \\
\hline Redox balance $\mathrm{O} / \mathrm{R}$ & 1.06 & 1.07 & 1.04 \\
\hline
\end{tabular}

* Expressed as mmol product per $100 \mathrm{mmol}$ NAG-equivalents fermented.

† Data from Pel \& Gottschal (1986).

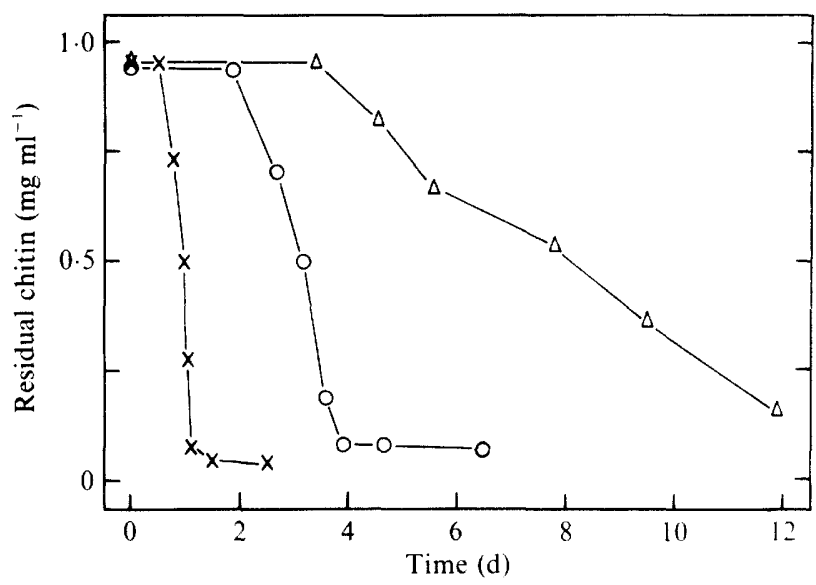

Fig. 1. Time course of chitinolysis in pure cultures of strain AW.D2 $(x)$ and Clostridium sp. strain $9.1(\triangle)$, and in a mixed culture of Clostridium sp. strain 9.1 and strain HA $8.1(0)$.

with strong reducing agents (e.g. dithionite, $0 \cdot 2 \mathrm{~mm}$ ), did not enhance anaerobic chitinolysis as it did for Clostridium sp. strain 9.1 (Pel \& Gottschal, 1986).

Anaerobic growth of strain AW.D2 was also supported by NAG-oligomers (tested up to $\mathrm{DP}=6$ ), glucosamine, glucose, fructose, arabinose, D-ribose, cellobiose, maltose and peptone. No growth occurred with gluconate, glucosaminic acid, xylose, lactose, saccharose, ethanol, propanol, butanol, glycerol, pyruvate, lactate, fumarate, succinate, chitosan, cellulose, starch, inulin, xylan, polygalactoaraban, polygalactomannan, agar, gelatin, Casamino acids or yeast extract. 

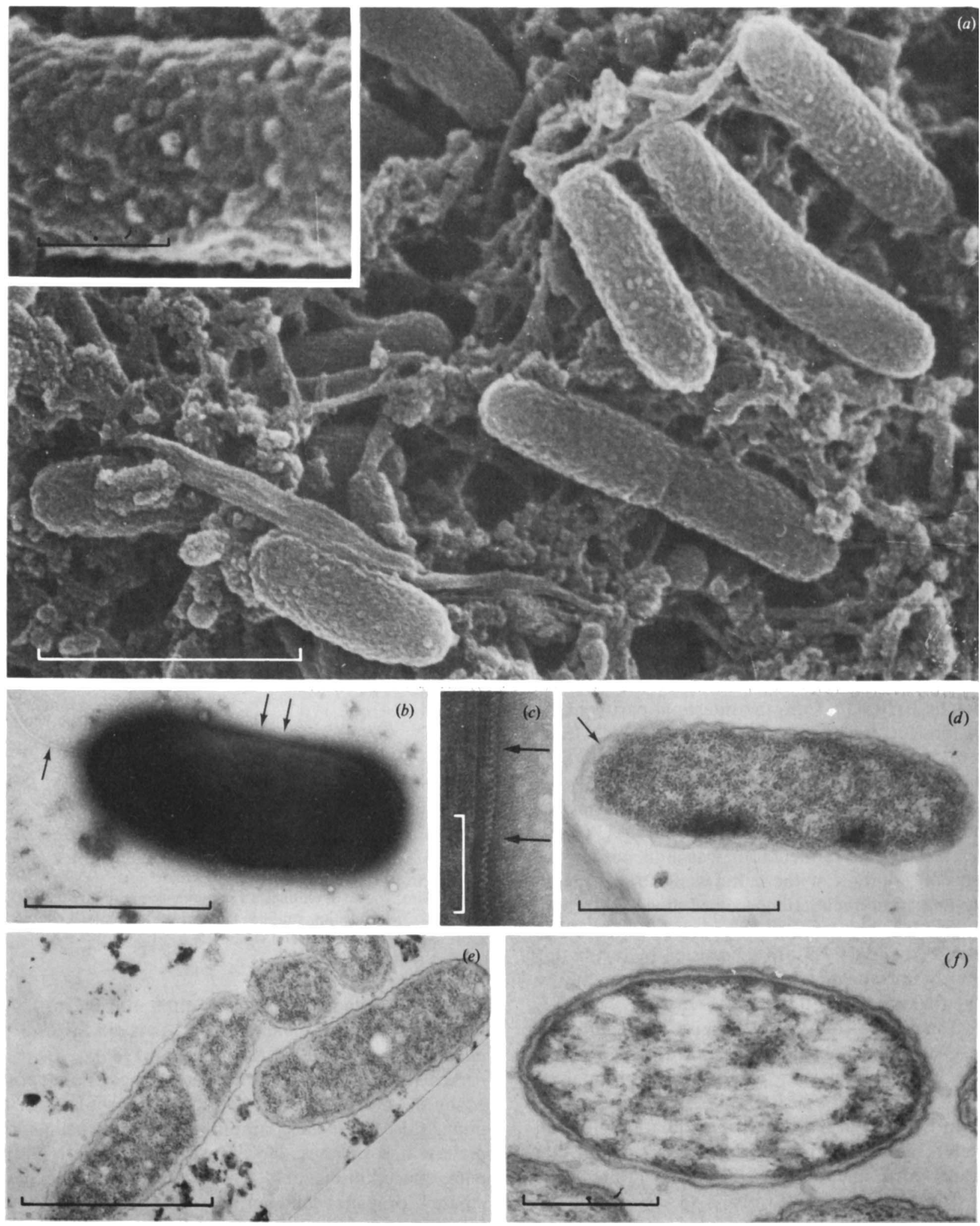

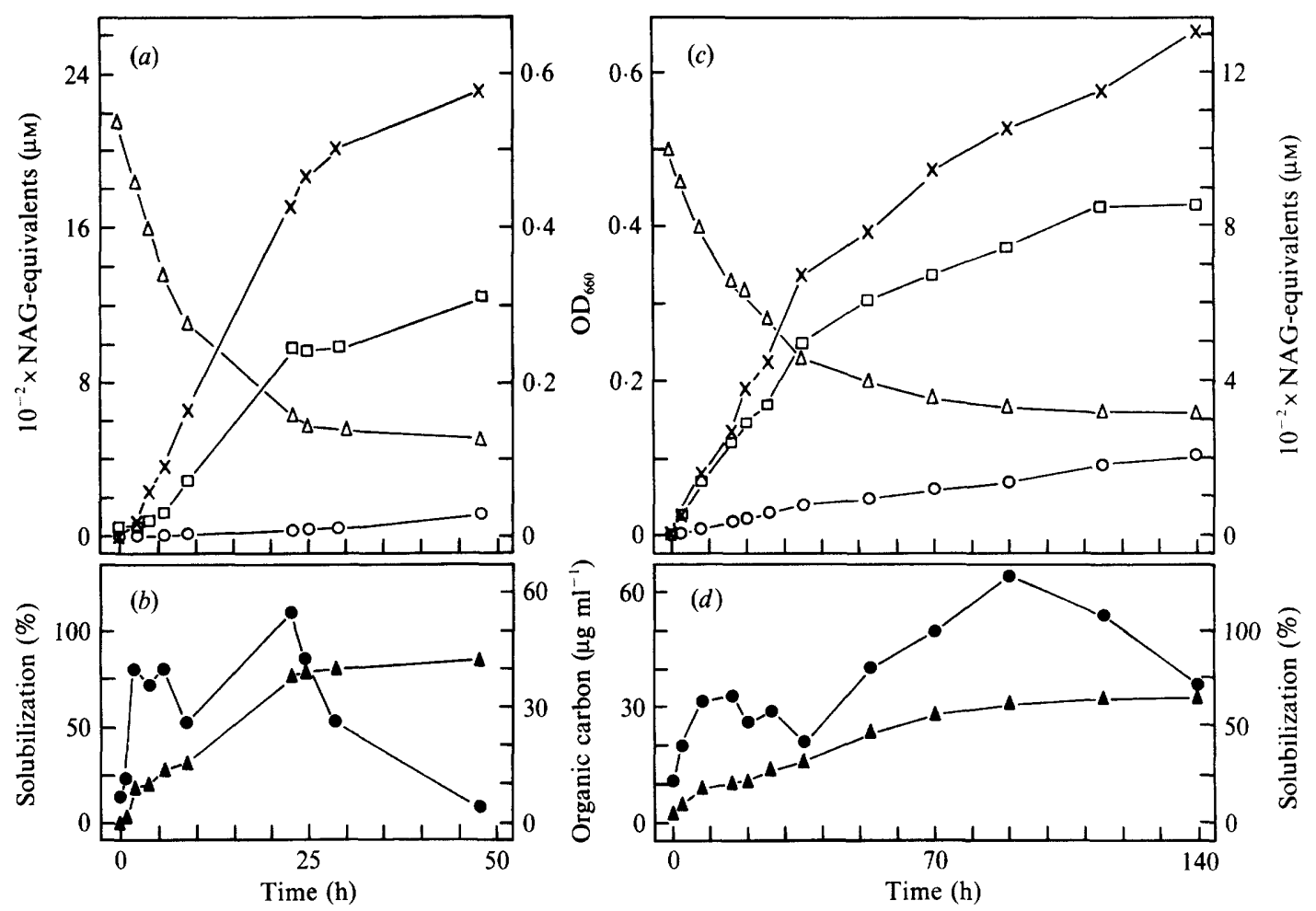

Fig. 3. Solubilization of chitin and the formation of hydrolysis products by the chitinase enzyme complexes of strain AW.D2 ( $a$, $b)$ and Clostridium sp. strain $9.1(c, d)$. $\triangle$, Turbidity of the chitin suspension; $\mathrm{O}, \mathrm{NAG} ; \times, \mathrm{NAG}_{2} ; \square$, total reducing sugar; $\boldsymbol{A}$, chitin solubilization; , organic carbon in the supernatant and not accounted for by NAG, NAG 2 and rifampicin. A solubilization of $100 \%$ corresponded to the formation of 295 and $275 \mu \mathrm{g}$ non-sedimentable organic carbon per ml supernatant for strain AW . D2 and strain 9.1 , respectively.

Scanning electron microscopy of strain AW.D2 revealed a rough outer surface of the cell wall with globular extensions (Fig. $2 a$ ). Negatively stained whole cells and thin sections showed the presence of a glycocalyx (Fig. 2b,d) and the formation and release of numerous vesicles (Fig. $2 e, f$ ). The formations of these vesicles was observed in all stages of growth, irrespective of whether chitin, $\mathrm{NAG}_{2}, \mathrm{NAG}$ or glucose served as the carbon and energy source. Negatively stained whole cells also demonstrated the presence of a regular spiral-shaped structure in the outer cell envelope (Fig. 2c).

\section{Hydrolytic and physico-chemical properties of chitinases of strain AW.D2 and strain 9.1}

Turbidimetric assays, combined with TOC and sugar analyses of the hydrolysis products, demonstrated that the enzyme complexes of strain AW.D2 and strain 9.1 were capable of extensive solubilization of chitin (Fig. $3 a-d)$. The hydrolysis of chitin by the chitinase of strain AW.D2 was almost complete after 45 h (i.e. about $85 \%$ solubilization, Fig. $3 b$ ), whereas the chitinolytic activity of the enzyme system of strain 9.1 was lower, resulting in approximately $65 \%$ solubilization of the substrate in $140 \mathrm{~h}$ (Fig. 3d). Both chitinolytic systems produced $\mathrm{NAG}_{2}$ as the major hydrolysis product, with an additional formation of small amounts of NAG (Fig. $3 a$, c). Soluble NAG-oligomers with DP $>2$ were not found using HPLC analysis.

The amount of total reducing sugars (DNS method) in both assays matched the sum of the individually determined amounts of chitobiose (HPLC analysis) and NAG, indicating the absence of substantial quantities of other sugars. However, a transient accumulation of nonsedimentable organic carbon was always observed in the

Fig. 2. (a) Scanning electron micrograph of a chitin-grown culture of strain AW.D2 in the stationary phase, showing the globular extensions on the outer surface of the cell wall. Bar, $1 \mu \mathrm{m}$. The inset shows a detail at higher magnification. Bar, $0 \cdot 2 \mu \mathrm{m}$. $(b)$ Negatively stained whole cell of strain AW.D2 grown on chitin showing glycocalyx (halo surrounding cell body), polar inserted flagellum (single arrow) and spiral-shaped structure in the cell wall (double arrows). Bar, $1 \mu \mathrm{m}$. (c) Detail of cell wall area indicated by the two arrows in (b). Bar $0 \cdot 1 \mu \mathrm{m}$. (d) Ultrathin section of a chitin-grown cell showing the presence of a glycocalyx (arrow). Bar, $1 \mu \mathrm{m}$. (e) Ultrathin section of chitin-grown cells showing the formation of vesicles. Bar, $1 \mu \mathrm{m}$. $(f)$ Formation of vesicles by a glucose-grown cell. Bar, $0 \cdot 2 \mu \mathrm{m}$. 


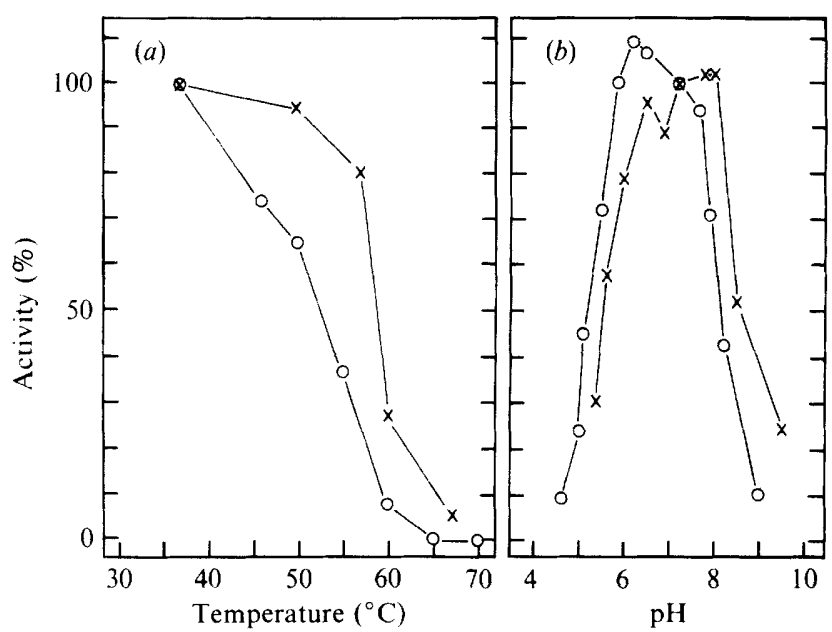

Fig. 4. Thermal stability $(a)$ and $\mathrm{pH}$ optima $(b)$ of the chitinase complexes of strain AW.D2 $(x)$ and Clostridium sp. strain $9.1(O)$. Thermal stability was determined by recording the residual hydrolytic activity following preincubation for $10 \mathrm{~min}$ at the indicated temperature. An activity of $100 \%$ corresponded to the formation of $300(a)$ and $250(b) \mu \mathrm{M}-\mathrm{NAG}_{2}$ in $40 \mathrm{~h}$ in the assay of strain 9.1 chitinase, and to 680 (a) and $660(b) \mu \mathrm{M}-\mathrm{NAG}_{2}$ in $26 \mathrm{~h}$ for strain AW.D2, under standard assay conditions.

Table 2. Effect of thiol and reducing agents on the activity of the chitinase complexes of strain $A W . D 2$ and Clostridium sp. strain 9.1

\begin{tabular}{lccccr}
\hline \hline & & \multicolumn{3}{c}{ Residual activity $(\%)$} \\
\cline { 3 - 4 } & & Strain AW.D2* & & \multicolumn{2}{c}{ Strain $9.1 \dagger$} \\
\cline { 3 - 3 } \cline { 5 - 6 } Reagent & $(\mu \mathrm{M})$ & $26 \mathrm{~h}$ & & $20 \mathrm{~h}$ & $50 \mathrm{~h}$ \\
\hline pCMB & 200 & 103 & & 0 & 0 \\
pCMPS & 200 & 104 & & 0 & 12 \\
IoAc & 200 & 101 & & 113 & 109 \\
$\mathrm{NEM}$ & 800 & 102 & & 47 & 32 \\
$\mathrm{Fe}(\mathrm{CN})_{6}$ & 300 & 101 & & 59 & 29 \\
$\mathrm{H}_{2} \mathrm{O}_{2}$ & 200 & 102 & & 88 & 76 \\
$\mathrm{O}_{2}$ & 240 & 94 & & 80 & 53 \\
Dithionite & 1000 & 97 & & ND & 110 \\
Dithiothreitol & 2000 & 103 & ND & 113 \\
\hline \hline
\end{tabular}

ND, Not determined.

* $100 \%$ activity corresponds to the formation of $710 \mu \mathrm{M}$-chitobiose in $26 \mathrm{~h}$.

$\dagger 100 \%$ activity corresponds to the formation of 115 and $230 \mu \mathrm{M}-$ chitobiose in 20 and $50 \mathrm{~h}$, respectively.

course of the enzyme assays (Fig. $3 b, d$ ). This surplus amounted to approximately $60 \mu \mathrm{g} \mathrm{C} \mathrm{ml}^{-1}$ in the enzyme assays; after acid hydrolysis it was found to consist of at least $50 \%$ glucosamine-positive material.

There was no detectable hydrolytic activity in the cellfree culture fluid of strain 9.1 and strain AW.D2 during the active growth phase. Release of soluble chitinase activity did occur when the cultures entered the stationary phase, but the activities were always lower than the sedimentable activity observed in the early growth phase, especially in the case of strain AW.D2. HPLC analyses indicated that for the cell-free enzyme activity $\mathrm{NAG}_{2}$ was again the major hydrolysis product $(>90 \%)$.

The difference in thermal stability of the enzyme complexes of strain AW.D2 and strain 9.1 is shown in Fig. 4(a). Pretreatment for $10 \mathrm{~min}$ at $50^{\circ} \mathrm{C}$ and lower did not affect the chitinolytic activity of strain AW.D2, whereas $10 \mathrm{~min}$ at $45^{\circ} \mathrm{C}$ resulted in a large drop in the chitinolytic activity of strain 9.1 . The activity of both chitinolytic systems displayed a broad $\mathrm{pH}$ range, with a slightly more acidic optimum for strain 9.1 (Fig. $4 b$ ).

Thiol reagents and oxygen did not significantly affect the hydrolytic activity of the enzyme complex of strain AW.D2 (Table 2). However, all thiol reagents tested, except IoAc, strongly inhibited the chitinase of strain 9.1 (Table 2), as indicated previously (Pel \& Gottschal, 1987).

\section{Regulation of chitinase synthesis}

Strain Aw.D2 exhibited a diauxic growth pattern when grown in a medium containing both chitobiose and chitin. Chitobiose was always consumed first. This was independent of whether the inoculum was pre-grown with chitin, chitobiose or NAG as the carbon and energy source. Only after depletion of chitobiose, and lag periods of 24 to $48 \mathrm{~h}$, was chitinase activity observed, but at a level five times lower than in cultures with chitin as the sole carbon and energy source (see Fig. 1). Upon transfer of cells from these cultures into fresh chitincontaining medium (without $\mathrm{NAG}_{2}$ ) the usual high rate of chitinolysis was observed. Scanning electron micrographs of the retarded cultures showed that chitin fibres were embedded in a mucous material. No chitinolytic activity was detected in supernatants or associated with cells of cultures of strain AW.D2 grown on glucose, glucosamine, NAG, $\mathrm{NAG}_{2}, \mathrm{NAG}_{3}$ or $\mathrm{NAG}_{5}$ (initial concn approx. $1 \mathrm{mg} \mathrm{ml}^{-1}$ ).

When strain 9.1 was grown in a medium containing both chitin and chitobiose the pattern of substrate utilization was quite different from that observed with strain AW.D2 (Fig. $5 a$ ) : both substrates were consumed simultaneously, though the initiation of chitin hydrolysis preceded the utilization of $\mathrm{NAG}_{2}$. Lowering the initial amount of chitin from 0.5 to $0.1 \mathrm{mg} \mathrm{ml}^{-1}$ did not change this pattern. The presence of thioredoxin (Pel \& Gottschal, 1989) stimulated chitin hydrolysis, and markedly enhanced the consumption of $\mathrm{NAG}_{2}$ (Fig $5 b$ ). The addition of NAG $(0.5 \mathrm{mM})$ or NAG-oligomers (DP $2-6,0.5 \mathrm{~mm}$ each) to chitin-grown cultures of strain 9.1 in 


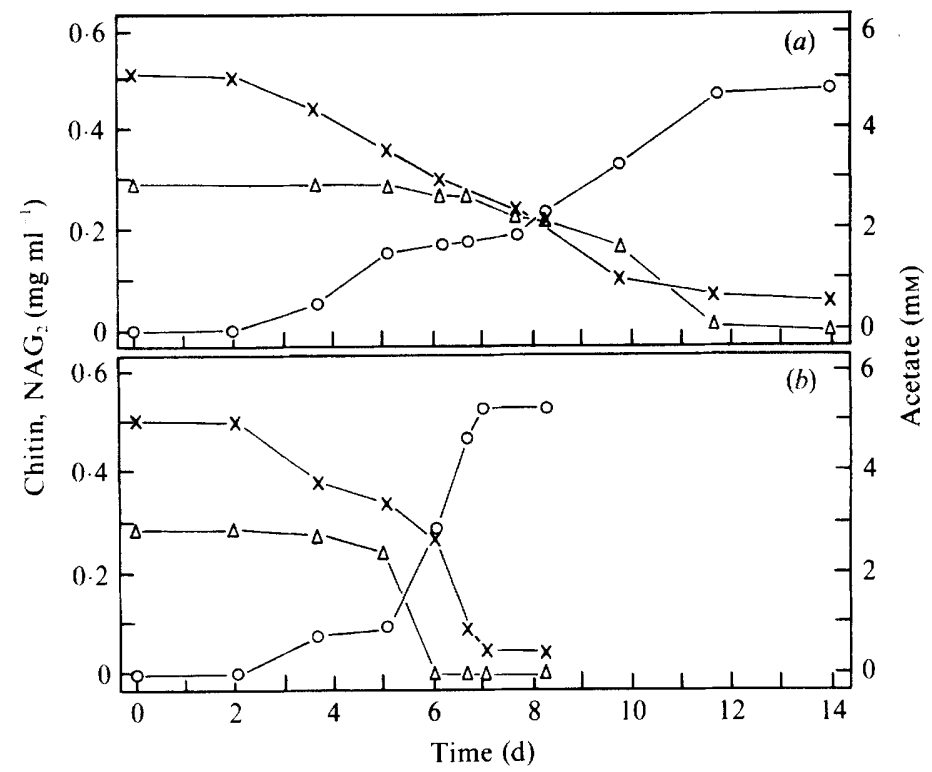

Fig. 5. Time course of the fermentation by Clostridium sp. strain 9.1 of chitin and $\mathrm{NAG}_{2}$ in the absence $(a)$ and the presence $(b)$ of thioredoxin $\left(0.5 \mu \mathrm{g}\right.$ protein per ml culture fluid). $\times$, Chitin; $\triangle, \mathrm{NAG}_{2} ; \mathrm{O}$, acetate.

the early growth phase (i.e. when $10 \%$ of the initial amount of chitin had been fermented) did not cause detectable changes in the rate of chitinolysis or fermentation (data not shown). NAG-oligomers with $\mathrm{DP} \geq 4$ disappeared from the culture fluid within $6 \mathrm{~h}$ of their addition, with a concomitant transient accumulation of only $\mathrm{NAG}_{2}$ (up to $1 \mathrm{mM}$ ) in the case of $\mathrm{NAG}_{4}$ and $\mathrm{NAG}_{6}$, and of $\mathrm{NAG}_{2}$ plus $\mathrm{NAG}_{3}$ (about $0.5 \mathrm{~mm}$ each) in the case of $\mathrm{NAG}_{5}$. The hydrolysis of $\mathrm{NAG}_{3}$ took almost $2 \mathrm{~d}$.

By increasing the amount of yeast extract in dithionitesupplemented cultures of strain 9.1 (Pel \& Gottschal, $1986,1987)$ the rate of fermentation could be increased (Fig. $6 b$ ) without proportionally enhancing the rate of chitin hydrolysis (Fig. 6a). As a result, decreasing amounts of $\mathrm{NAG}_{2}$ accumulated transiently in the culture fluid when the concentration of yeast extract was raised from 0.005 to $0.04 \%$ (w/v) (Fig. 6c). If dithionite was omitted the rate of chitinolysis decreased considerably (Fig. 6a).

\section{Competition for chitin in mixed cultures}

Unlike the growth of Clostridium sp. strain 9.1 (Pel et al., 1989; Pel \& Gottschal, 1989), growth of strain AW.D2 was not significantly affected by the presence of NAG (-oligomer)-fermenting bacteria such as strain HA 8.1, strain GH 8.2, E. coli and $K$. pneumoniae. Moreover, only very low numbers of saccharolytic bacteria could be sustained in cultures of strain AW.D2.

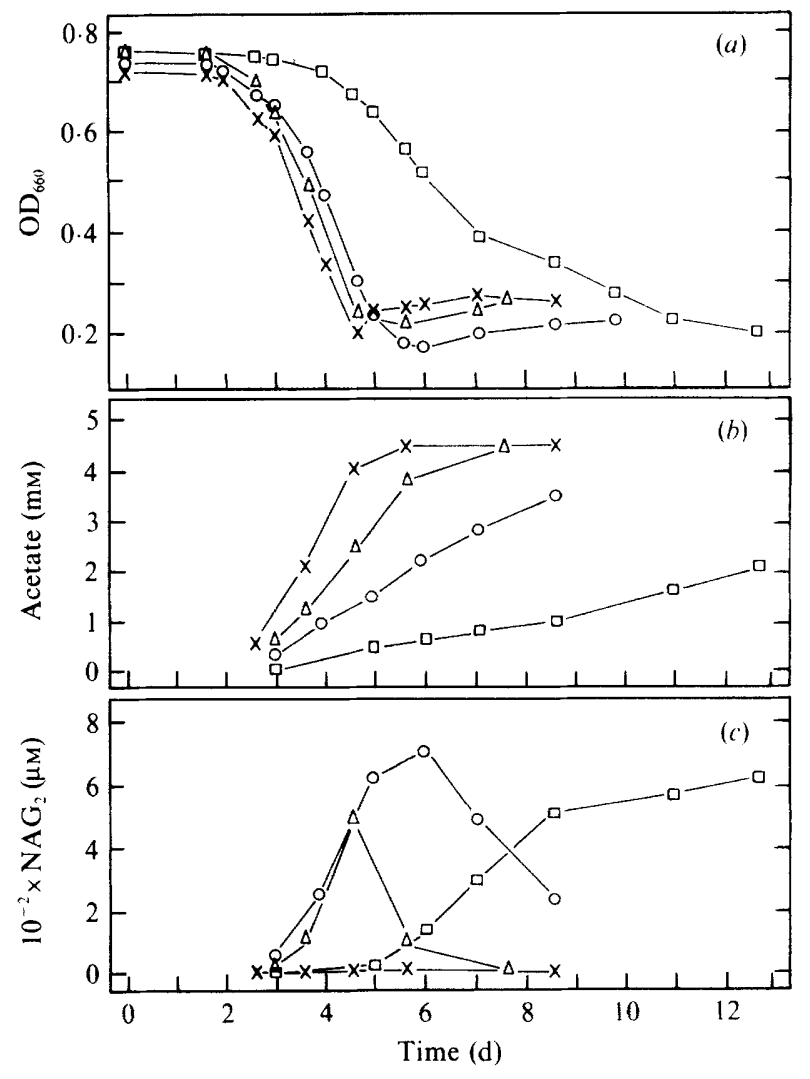

Fig. 6. Combined effects of dithionite and yeast extract concentration on chitin fermentation by Clostridium sp. strain 9.1. $O, \triangle, x$, Addition of $0.005 \%(O), 0.02 \%(\triangle)$ or $0.04 \%(x)$ yeast extract plus 0.2 mm-dithionite; $\square$, addition of $0.005 \%$ yeast extract, dithionite omitted. (a) Solubilization of chitin recorded as the decrease in $\mathrm{OD}_{660}$ of the culture; (b) acetate formation; $(c) \mathrm{NAG}_{2}$ accumulation.

When strain AW.D2 and Clostridium sp. strain 9.1 were cocultured with chitin as the sole carbon and energy source, co-existence was not established. The latter organism was always completely outcompeted after one or two transfers (inoculum $1 \%, \mathrm{v} / \mathrm{v}$ ) in fresh medium. A similar result was obtained when the $\mathrm{pH}$ of the culture medium was lowered to a more favourable value for strain 9.1 (i.e. 6.0) or when the inoculum size of strain AW.D2 was reduced 100 -fold. However, the introduction of a third organism, strain HA 8.1, improved the competitiveness of strain 9.1 dramatically. Thus, in the presence of strain HA 8.1, strain 9.1 outcompeted strain AW.D2 after two transfers in batch culture. This was indicated by the decrease in numbers of strain AW.D2 cells (Table 3). Further support for a transition from the three-membered culture to a two-membered strain 9.1 plus strain HA 8.1 culture comes from the increasing concentration of propionate in the stationary phase, as propionate is a characteristic fermentation product of strain HA 8.1, but is formed neither by strain 9.1 nor by strain AW.D2 (Table 3). 
Table 3. Competition for chitin in batch and phauxostat cultures between strain AW.D2 and Clostridium sp. strain 9.1

\begin{tabular}{|c|c|c|c|c|c|c|c|}
\hline & \multicolumn{7}{|c|}{ Products and number of cells detected in stationary phase (batch*) or steady state (phauxostat $\dagger$ ): } \\
\hline & \multicolumn{5}{|c|}{ Batch cultures } & \multirow{2}{*}{\multicolumn{2}{|c|}{$\frac{\text { Phauxostat cultures }}{\text { Mixed culture }:}$}} \\
\hline & \multirow[b]{2}{*}{$\begin{array}{l}\text { Pure culture } \\
\text { of AW.D2 }\end{array}$} & \multirow[b]{2}{*}{$\begin{array}{c}\text { Coculture: } \\
9.1+\text { HA } 8.1\end{array}$} & \multicolumn{3}{|c|}{$\begin{array}{c}\text { Mixed culture: } \\
9.1+\text { HA 8.1 + AW.D2 }\end{array}$} & & \\
\hline & & & $0^{\mathrm{N}}$ & $\begin{array}{l}\mathrm{f} \text { batch } \mathrm{t} \\
1\end{array}$ & fers: 2 & $D=0.04 \mathrm{~h}^{-1}$ & $D=0.08 \mathrm{~h}^{-1}$ \\
\hline Acetate (mM) & $7 \cdot 2$ & 5.8 & $6 \cdot 6$ & $6 \cdot 2$ & 5.9 & $2 \cdot 4$ & $2 \cdot 7$ \\
\hline Propionate (mM) & - & $1 \cdot 2$ & 0.6 & 0.9 & 1.0 & 1.0 & 1.0 \\
\hline Ethanol (mM) & 3.2 & $1 \cdot 3$ & ND & ND & ND & ND & ND \\
\hline $\begin{array}{l}10^{-6} \times \text { AW. D2 cells } \mathrm{ml}^{-1} \ddagger \\
10^{-6} \times \text { HA } 8.1 \text { cells } \mathrm{ml}^{-1} \ddagger\end{array}$ & $230 \pm 20$ & $\begin{array}{c}- \\
750 \pm 210\end{array}$ & $\begin{array}{l}90 \pm 20 \\
\mathrm{ND}\end{array}$ & $\begin{array}{l}44 \pm 20 \\
\text { ND }\end{array}$ & $0 \cdot 3 \pm 0.61$ & $\begin{array}{c}1 \pm 0 \cdot 8 \\
250 \pm 7\end{array}$ & $\begin{array}{c}2 \pm 0 \cdot 5 \\
280 \pm 58\end{array}$ \\
\hline
\end{tabular}

ND, Not determined; -, not detected.

* The initial amount of chitin in batch culture experiments was $1 \mathrm{mg} \mathrm{ml}^{-1}$.

† Steady-state chitin concentrations in the culture were 0.19 and $0.24 \mathrm{mg} \mathrm{ml}^{-1}$ at $D=0.04$ and $0.08 \mathrm{~h}^{-1}$, respectively. The amount of chitin solubilized in the phauxostat was approximately $0.4 \mathrm{mg} \mathrm{ml}^{-1}$.

$\ddagger$ Mean of two or three determinations \pm standard deviation.

The competitiveness of the two chitinolytic species was also tested under chitin limitation in a phauxostat at dilution rates of 0.04 and $0.08 \mathrm{~h}^{-1}$, and steady-state chitin concentrations of 0.19 and $0.24 \mathrm{mg} \mathrm{ml}^{-1}$, respectively. Strain 9.1 and strain HA 8.1 were cocultured until a steady state was reached, prior to the inoculation of strain AW.D2. Strain AW.D2 was not completely washed out but remained present with a constant but very small number of cells (Table 3). The number of cells $\left(1-2 \times 10^{6} \mathrm{ml}^{-1}\right)$ represented the consumption of approximately $2 \%$ of the chitin fermented, based on the results obtained with pure cultures of strain AW.D2.

\section{Discussion}

Aerobic plate counts indicated that $10^{7}-10^{9}$ chitinolytic bacteria $\mathrm{ml}^{-1}$ occur in the digestive tract of marine fish consuming chitin-containing food (Seki \& Taga, 1963; Goodrich \& Morita, 1977; Danulat, 1986). Our anaerobic isolation and enumeration procedure suggests that in spite of the anoxic conditions in the intestinal tract a facultatively anaerobic bacterium predominated over strictly anaerobic chitinolytic species in the hindgut of the plaice, Pleuronectes platessa.

The $\mathrm{pH}$ optimum for growth and chitin hydrolysis of strain AW.D2 was in the range $7 \cdot 0-8 \cdot 0$, reflecting its adaptation to the prevailing $\mathrm{pH}$ values occurring in the intestinal tract of fish [cod, 7-8 (Danulat, 1986); plaice, 7.4-8.4 (Barrington, 1957)]. The formation of vesicles and blebs during growth on chitin and various sugars could be the result of a continuous synthesis of a glycocalyx-like coat surrounding the cell envelope of strain AW.D2. The presence of a glycocalyx has been implicated in protection against anti-bacterial agents such as surfactants (e.g. bile salts: Costerton et al., 1981).

The importance of the degradation of chitin in the intestines of marine fish has been questioned because of an apparently low in situ chitinolytic activity of the gut micro-organisms (Danulat, 1986; Seki \& Taga, 1963). However, considering the high numbers of chitinolytic bacteria in the intestinal tract of $P$. platessa, the strong hydrolytic activity of strain AW.D2 and the residence time of the food in the digestive tract of plaice $(12-24 \mathrm{~h}$ : Fänge \& Grove, 1979), extensive degradation of chitinous material passing through the intestines has to be expected. The low in situ chitinolytic activities detected in cod by Danulat (1986) were probably severe underestimates, since the activity associated with solid particles in the intestines was not accounted for in the assays.

The extracellular chitinolytic enzyme systems of strain AW.D2 and Clostridium sp. strain 9.1 both release $\mathrm{NAG}_{2}$ as the major hydrolysis product from chitin. The actual uptake of $\mathrm{NAG}_{2}$ by strain 9.1 is implicated by the organism's very poor growth on NAG and related monosaccharides (Pel \& Gottschal, 1986). The absence of an extracellular chitobiase activity in chitin-grown cultures of strain AW.D2 also suggests the presence of a transport system for the dimer in this organism. The formation and uptake of disaccharides is a fairly common feature of strictly anaerobic polysaccharidedegrading species (Saddler \& Khan, 1979; Hiltner \& Dehority, 1983; Patel et al., 1980). This may be due to the more favourable energetics of dimer transport compared with that of monomers via PTS systems, and the ATP gain obtained by the action of intracellular disaccharide- 
phosphorylases (Martin \& Russell, 1987). However, the uptake of $\mathrm{NAG}_{2}$ has never been demonstrated, nor suggested, for chitin-degrading (facultatively) aerobic species such as Serratia marcescens (Monreal \& Reese, 1969), Beneckea neptuna and Beneckea nereida (gut endosymbionts in the white shrimp) (Hood \& Meyers, 1977) and Streptomyces griseus (Berger \& Reynolds, 1958).

Analyses of the products formed during the solubilization of chitin by the enzyme complexes of strain AW.D2 and strain 9.1 revealed the transient accumulation of a hydrolysis product(s), which could not be identified by HPLC. This intermediate product consisted of glucosamine-containing material but was not pelleted by centrifugation at $8500 \mathrm{~g}$ for $5 \mathrm{~min}$. The formation of similar fractions has also been found during the degradation of cellulose by Clostridium thermocellum (Weimer \& Chou, 1986) and Trichoderma reesei (Enari \& Niku-Paavola, 1987). Studies on the enzymic degradation of insoluble polysaccharides usually concentrate on residual (= sedimentable) substrate and truly soluble hydrolysis products. So far, little attention has been paid to products of intermediate (colloidal) character. However, a more detailed knowledge of the formation, composition and properties of such intermediate products seems essential for the complete elucidation of the hydrolytic mechanism involved in the degradation of crystalline polysaccharides (Enari \& Niku-Paavola, 1987).

The enzyme complexes of strain 9.1 and strain AW.D2 show much resemblance with respect to some general properties (formation of $\mathrm{NAG}_{2}$ and absence of extracellular chitobiase) but differ in temperature stability, pH optima and susceptibility to thiol reagents. The insensitivity of the chitinolytic enzyme system of strain AW.D2 to thiol reagents and strong reductants indicates the absence of accessible and essential thiol or disulphide groups. These results are in agreement with the observation that normally cyst(e)ine is not present in extracellular proteins produced by facultatively anaerobic bacteria (Fahey et al., 1977).

Chitinase is not a constitutive enzyme in strain AW.D2, as indicated by the growth pattern in media containing both chitin and chitobiose, and because no chitinolytic activity was detected in the culture fluid or associated with the cells when the bacterium was grown on NAG-oligomers (DP $\geq 2$ ). It is not clear whether NAG-oligomers do not induce chitinase synthesis, or carbon and energy limitation is required for its derepression or induction. In contrast to strain AW.D2, no repression of chitinase synthesis by chitobiose occurs in strain 9.1. This has also been reported for other specialized polysaccharide-degrading anaerobes only capable of utilizing the polymer or oligomers with
DP $\geq 2$ (Hiltner \& Dehority, 1983; Garcia-Martinez et al., 1980). Interestingly, the initiation of chitinolysis in cultures of strain 9.1 occurs $2-4 \mathrm{~d}$ prior to the uptake of $\mathrm{NAG}_{2}$ when chitin and the disaccharide are both present in the culture medium. This phenomenon, perhaps indicating the organisms' initial preference for $\mathrm{NAG}_{2}$ derived directly from chitin, warrants a more detailed examination of sugar transport across the cell membrane in this bacterium, especially since polymer hydrolysis is generally considered the rate-limiting step in the growth of polysaccharide-degrading bacteria.

In a previous paper, chitinolysis by Clostridium sp. strain 9.1 was shown to be relatively unaffected by the consumption of $10-70 \%$ of the total hydrolysis products by secondary populations ( $\mathrm{Pel}$ et al., 1989). It is remarkable that in pure cultures with a greatly decreased rate of fermentation due to low yeast extract concentrations (Fig. $6 b$ ), the rate of chitin hydrolysis also remains unaffected if the reducing agent dithionite is present (Fig. 6). In such cultures a considerable transient accumulation of $\mathrm{NAG}_{2}$ occurred, up to $50 \%$ of the quantity of chitin hydrolysed. It is tempting to speculate that in nature the secondary population(s) sustained by strain 9.1 participate directly in maintaining a high chitinolytic activity by releasing stimulatory growth factors (e.g. the redox-active enzyme thioredoxin : see Pel \& Gottschal, 1989; Pel et al., 1989), and at the same time increase the competitiveness of strain 9.1 by consuming the hydrolysis products formed by other competing chitin-degrading species. The constitutive nature of the chitinolytic activity of strain 9.1, together with a substantial consumption of the hydrolysis products by strain HA 8.1, is likely to be one of the reasons why the Clostridium species outcompeted strain AW.D2. Further, it is of importance that in mixed cultures of strain 9.1 plus strain HA 8.1 plus Clostridium acetobutylicum and of strain 9.1 plus $C$. acetobutylicum, $C$. acetobutylicum reached similar final cell densities (unpublished data). This indicates that in both mixed cultures NAG was available equally well for this organism (although C. acetobutylicum is only capable of using the chitin monomer, it succeeds in consuming 13$16 \%$ of the hydrolysis products: see Pel et al., 1989). This suggests that the strain HA 8.1 does not compete very effectively for the monomer, thus leaving NAG accessible to other organisms, such as strain AW.D2 in the above triculture on chitin. As a result the chitinolytic enzyme system of strain AW.D2 is probably subject to (partial) repression. The combination of these factors represents the first documented example for polysaccharide-degrading cultures of a cooperation between a primary and a secondary species resulting in an increase in the competitiveness of both (Fig. 7).

The question has been raised (Pel \& Gottschal, 1986) 


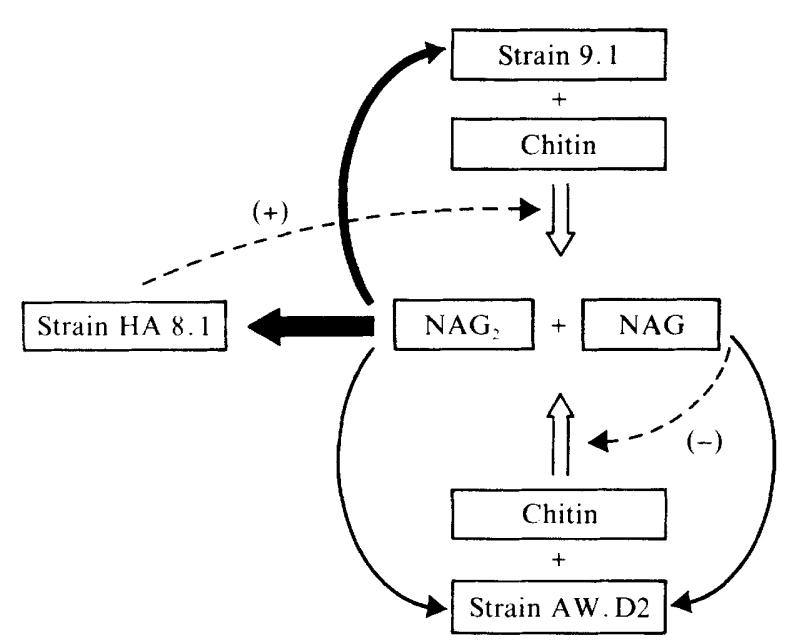

Fig. 7. Hypothetical representation of the flow of chitin hydrolysis products and the species interactions in a triculture consisting of the two chitinolytic bacteria, Clostridium sp. strain 9.1 and strain AW . D2, and the non-chitinolytic strain HA 8.1. $\Rightarrow$. Formation of hydrolysis products $; \longrightarrow$, consumption of hydrolysis products. Thickness of the lines represents the quantitative importance of the flow of sugars [see also Pel et al. (1989) for sugar consumption in two-membered cocultures]; $\cdots$, , regulatory interaction; $(+)$, stimulatory (growth) factors (see Pel et al., 1989); (-), repression of chitinase synthesis.

why in anaerobic enrichments on chitin from sediment samples (made on four separate occasions) a rapidly chitin-degrading species like strain AW.D2 never became the dominant organism, in spite of its continuous 'inoculation' of the sediment surface via the faeces of flatfish such as plaice. Apparently the inferior competitiveness of the more versatile chitinolytic species from the fish-gut under conditions of continuous growth on chitin precludes its widespread occurrence in the sediment. This more opportunistic type of organism, with an inducible/repressible chitinolytic system, is clearly far better adapted to the strongly fluctuating food conditions encountered in animal intestines.

Thanks are due to Klaas A. Sjollema and Jan Zagers for the preparation of the electron micrographs.

\section{References}

Barrington, E. J. W. (1957). Alimentary canal and digestion. In The Physiology of Fish, vol. I, pp. 109-161. Edited by M. Brown. New York: Academic Press.

BERGER, L. R. \& REYNOLDS, D. M. (1958). The chitinase system of Streptomyces griseus. Biochimica et Biophysica Acta 29, 522-534.

Chen, G. C. \& Johnson, B. R. (1983). Improved colorimetric determination of cell wall chitin in wood decay fungi. Applied and Environmental Microbiology 46, 13-16.

COSTERton, J. W., IRvin, R. T. \& Cheng, K.-J. (1981). The bacterial glycocalyx in nature and disease. Annual Review of Microbiology 35, 299-324.

DANULAT, E. (1986). Role of bacteria with regard to chitin degradation in the digestive tract of the cod Gadus morhua. Marine Biology 90 , $335-343$
ENARI, T.-M. \& NiKU-PaAvola, M.-L. (1987). Enzymatic hydrolysis of cellulose: is the current theory of the mechanism of hydrolysis valid? CRC Critical Reviews in Biotechnology 5, 67-87.

Fahey, R. C., Hunt, J. S. \& Windham, G. C. (1977). On the cysteine and cystine content of proteins: differences between intracellular and extracellular proteins. Journal of Molecular Evolution 10, 155160.

Fänge, R. \& Grove, D. J. (1979). Digestion. In Fish Physiology, vol. VIII, pp. 162-260. Edited by W. S. Hoar, D. J. Randall \& J. R. Brett. New York: Academic Press.

Garcia-Martinez, D. V., Shinmyo, A., Madia, A. \& Demain, A. L. (1980). Studies on cellulase production by Clostridium themocellum. European Journal of Applied Microbiology and Biotechnology 9, 189197.

Goodrich, T. D. \& MoRita, R. Y. (1977). Bacterial chitinase in the stomachs of marine fish from Yaquina Bay, Oregon, USA. Marine Biology 41, 355-360.

HiltNER, P. \& DeHORITY, B. A. (1983). Effect of soluble carbohydrates on digestion of cellulose by pure cultures of rumen bacteria. Applied and Environmental Microbiology 46, 642-648.

HOOD, M. A. \& MEYERS, S. P. (1977). Microbiological and chitinoclastic activities associated with Penaeus setiferus. Journal of the Oceanographical Society of Japan 33, 235-241.

Johnson, E. A., Sakajoh, M., Hall well, G., Madia, A. \& Demain, A. L. (1982). Saccharification of complex cellulosic substrates by the cellulase system of Clostridium thermocellum. Applied and Environmental Microbiology 43, 1125-1132.

Mackenzie, C. R., Bilous, D. \& Patel, G. B. (1985). Studies on cellulose hydrolysis by Acetivibrio cellulolyticus. Applied and Environmental Microbiology 50, 243-248.

Martin, G. A. \& Hempfling, W. P. (1976). A method for the regulation of microbial population density during continuous culture at high growth rates. Archives of Microbiology 107, 41-47.

Martin, S. A. \& Russell, J. B. (1987). Transport and phosphorylation of disaccharides by the ruminal bacterium Streptococcus bovis. Applied and Environmental Microbiology 53, 2388-2393.

MoNREAL, J. \& ReESE, E. T. (1969). The chitinase of Serratia marcescens. Canadian Journal of Microbiology 15, 689-696.

Miller, G. L. (1959). Use of dinitrosalicylic acid reagent for determination reducing sugar. Analytical Chemistry 3, 426-428.

Patel, G. B., Khan, A. W., Agnew, B. J. \& Colvin, J. R. (1980) Isolation and characterization of an anaerobic, cellulolytic microorganism, Acetivibrio cellulolyticus gen. nov., sp. nov. International Journal of Systematical Bacteriology 30, 179-185.

Pel, R. \& GotTschal, J. C. (1986). Mesophilic chitin-degrading anaerobes isolated from an estuarine environment. FEMS Microbiology Ecology 38, 39-49.

PeL, R. \& GotTSCHAL, J. C. (1987). The effect of oxygen and sulfhydryl reagents on the hydrolysis and the fermentation of chitin by Clostridium sp. strain 9.1. FEMS Microbiology Letters 44, 59-62.

PeL, R., \& GotTSCHAL, J. C. (1989). Interspecies interaction based on transfer of a thioredoxin-like compound in anaerobic chitindegrading mixed cultures. FEMS Microbiology Ecology 62, 349-357.

Pel, R., Hessels, G., Aalfs, H. \& GotTschal, J. C. (1989). Chitin degradation by Clostridium sp. strain 9.1 in mixed cultures with saccharolytic and sulfate-reducing bacteria. FEMS Microbiology Ecology 62, 191-200.

SADDLER, J. M. \& KHAN, A. W. (1979). Cellulose degradation by a new isolate from sewage sludge, a member of the Bacteriodaceae family. Canadian Journal of Microbiology 25, 1427-1431.

SEKI, H. \& TAGA, N. (1963). Microbiological studies on the decomposition of chitin in marine environments, $\mathrm{V}$ : Chitinoclastic bacteria as symbionts. Journal of the Oceanographical Society of Japan 19, 38-41.

Skujins, J., Pukite, A. \& Mclaren, A. D. (1970). Chitinase of Streptomyces sp.: purification and properties. Enzymologia 39, 353370.

STAM, A. (1984). De vissen, krabben en garnalen van het Eems-Dollard estuarium, III, Kwantitatieve inventarisatie van de platvissen, BOEDE-Publicatie en Verslagen, no. 2

WEIMER, P. J. \& CHOU, Y.-C. T. (1986). Anaerobic fermentation of woody biomass pretreated with supercritical ammonia. Applied and Environmental Microbiology 52, 733-736. 